\title{
Mechanisms of bradykinin-induced contraction in human fetal lung fibroblasts
}

\author{
L. Petecchia*,f, F. Sabatini*,f, C. Usai ${ }^{\#}$, S. Carnevali ${ }^{\dagger}$, M. Ognibene $^{+}$, C. Vanni ${ }^{+}$,

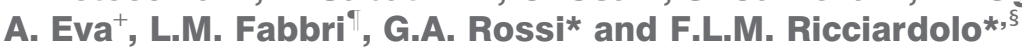

ABSTRACT: Bradykinin (BK) induces fibroblast contraction but the structural changes and intracellular mechanisms involved have not been completely explored.

We stimulated HFL-1 fibroblasts with BK to assess: 1) fibroblast contractility; 2) the role of $\alpha$ smooth muscle actin (SMA) in contraction by small interfering RNA (siRNA); 3) $\alpha$-SMA protein expression; 4) $\alpha$-SMA and F-actin structure; 5) intracellular calcium concentration $\left(\left[\mathrm{Ca}^{2+}\right]_{\mathrm{i}}\right)$; and 6) phosphorylated myosin light-chain (pMLC) and MLC kinase (MLCK) expression.

BK triggered concentration- and time-dependent fibroblast gel contraction in conjunction with $\alpha$-SMA over expression, but not in $\alpha$-SMA-siRNA-treated cells. BK also increased $\alpha-S^{+}$and Factin $^{+}$cell number and stress fibre polymerisation (detectable at 5-60 min). These BK-induced changes were associated with an increase in $\left[\mathrm{Ca}^{2+}\right]_{i}$, which peaked within $15 \mathrm{~s}$, and activation of pMLC, which was detectable at 5-60 min. No MLCK content modification was observed. The different manifestations of the BK-induced fibroblast activation were downregulated at different levels (25-100\%) by HOE140, a specific BK B2 receptor (B2R) antagonist and by the $\mathrm{Ca}^{2+}$ chelator, EGTA.

Thus, BK-induced fibroblast contraction, associated with differentiation into $\alpha$-SMA ${ }^{+}$myofibroblasts, is mediated through the activation of the B2R and involves the $\mathrm{Ca}^{2+} /$ calmodulin pMLCdependent pathway.

KEYWORDS: $\alpha$-Smooth muscle actin, calcium, contraction, fibroblasts, myosin phosphorylation

B radykinin $(\mathrm{BK})$ and the related peptide kallidin (KD or lys-BK) are formed from high- and low-molecular weight kininogen precursors following the activation of plasma and tissue kallikreins by various stimuli leading to inflammation, tissue damage and remodelling [1]. Two distinct mammalian BK receptor subtypes have been characterised based on their pharmacological properties: the constitutive B2 receptor $(\mathrm{B} 2 \mathrm{R})$ and the inducible $\mathrm{B} 1$ receptor (B1R), which shows high affinity for the carboxyl terminally truncated kinins [des-Arg 9 ]-bradykinin and [des-Arg $\left.{ }_{10}\right]-k a l l i d i n$ [2]. Activation of the B2R, a G-protein-coupled receptor constitutively expressed on most cell types, leads to a number of intracellular events, including activation of phospholipase $\mathrm{A}_{2}$ and $\mathrm{C}$ and mitogen-activated protein kinase phosphorylation [3]. In contrast, B1 receptors are not present in tissues under normal conditions but their expression can be induced during inflammation or tissue injury [4].

Functional and biochemical evidences prove the presence of kinin receptors in many cell types in the respiratory tract, including vagal sensory nerve fibres, epithelial and seromucous cells, smooth muscle cells and fibroblasts $[5,6]$. In disorders such as asthma, BK has been show to induce acute inflammatory responses, with plasma protein extravasation, mucus hypersecretion and smooth muscle contraction [7, 8]. In addition, BK may be involved in the repair processes in chronic inflammatory diseases of the airways through its ability to induce fibroblast proliferation and differentiation into $\alpha$ smooth muscle actin (SMA)-positive myofibroblasts [9].

During differentiation into myofibroblasts, lung fibroblasts develop cytoskeletal features similar to those of smooth muscle cells, as they express myosin chains and a contractile isoform of $\alpha$-SMA actin and promote contractility of the surrounding lung parenchymal components [10]. The exertion of tractional force on extracellular matrix components is dependent on the spatial and temporal pattern of myosin light-chain (MLC) phosphorylation and is controlled by the MLC kinase (MLCK) $\mathrm{Ca}^{2+}$-dependent pathway, which requires the influx of $\mathrm{Ca}^{2+}$ from the extracellular space or the release of $\mathrm{Ca}^{2+}$ from sequestered internal stores: calcium-dependent contraction [11]. In
AFFILIATIONS

*Pulmonary Unit, G. Gaslini Institute, and

+Laboratory of Molecular Biology, G. Gaslini Institute, and

\#Institute of Biophysics, National Research Council, Genoa,

"Pulmonary Unit, Modena University, Modena, and

${ }^{\S}$ Clinic of Respiratory Disease, Dept of Clinical and Biological Sciences, University of Turin, Turin, Italy. ${ }^{f}$ Both authors are joint first authors.

CORRESPONDENCE

G.A. Rossi

Pulmonary Diseases Unit

G. Gaslini Institute

Largo G. Gaslini 5

16147 Genoa

Italy

E-mail: giovannirossi@ospedalegaslini.ge.it

Received:

July 162009

Accepted after revision:

March 072010

First published online:

March 292010 
lung tissues from asthmatic patients, upregulation of smoothmuscle MLCK mRNA is associated with increased cell contractility and, through mathematical models, it was shown that a higher total MLCK led to a higher MLCK activity [12]. Other mechanisms of force generation independent of MLC phosphorylation have also have described [13], such as the activation of Rho and Rho kinase pathway [11] dependent on inhibition of MLC phosphatase [14].

The demonstration that BK may promote fibroblast differentiation into $\alpha$-SMA-positive myofibroblasts [9] and may induce contraction of the surrounding parenchymal components [15] further underlines the complex role that this kinin may have in tissue dysfunction in chronic inflammatory diseases, such as asthma.

BK-induced fibroblast-mediated contraction of collagen gel was detectable after 30-60 min of incubation, appeared to be mediated through phospholipase $C$ and was, at least partially, dependent on protein kinase $\mathrm{C}$ activation and intracellular $\mathrm{Ca}^{2+}\left(\left[\mathrm{Ca}^{2+}\right]_{\mathrm{i}}\right)$ mobilisation [15].

Whether and to what extent BK-induced lung fibroblastmediated contraction of collagen gel is associated with a contemporary differentiation in $\alpha$-SMA expressing myofibroblasts and, as demonstrated in airway smooth muscle, with the involvement of MLC phosphorylation is still undefined.

Therefore, an in vitro study was designed to assess the timedependent fibroblasts contraction, $\alpha$-SMA expression and structure, $\left[\mathrm{Ca}^{2+}\right]_{i}$ mobilisation, and phosphorylated MLC and MLCK expression in human fetal lung fibroblasts.

\section{METHODS}

\section{Fibroblast culture}

Human fetal lung fibroblasts (HFL-1; lung, diploid and human) were obtained from the American Type Culture Collection (Manassas, VA, USA). HFL-1 fibroblasts were cultured in Dulbecco's modified Eagle's medium (DMEM; Euroclone Ltd, Paignton, UK) containing 10\% fetal calf serum, and penicillin/streptomycin (Euroclone Ltd), and used for experiments from passage 11 to 21 .

\section{Small interfering RNA and transfection}

Small interfering RNA (siRNA) for $\alpha$-SMA and nonspecific siRNA for control were purchased from Dharmacon (SMARTpool; EuroClone, S.p.A, Milan, Italy). Transfection of siRNA was performed as previously described [16].

\section{Experiment design}

To assess fibroblast-gel contraction, HFL-1 were embedded in collagen gels, cultured for 5 days and then stimulated with BK (0.01-1 $\mu \mathrm{M})$ for different time-periods (30, 60 or $120 \mathrm{~min}$ ). After transfection with $\alpha$-SMA, siRNA cells were cultured for $60 \mathrm{~min}$ in the presence or absence of BK. $\alpha$-SMA and F-actin expression were evaluated 5, 15, 30 and 60 min after BK $(1 \mu \mathrm{M})$ incubation. $\mathrm{Ca}^{2+}$ mobilisation was evaluated in fibroblasts stimulated with BK (0.001-1 $\mu \mathrm{M})$. MLC phosphorylation was evaluated 5, 15, 30 and $60 \mathrm{~min}$ after BK $(1 \mu \mathrm{M})$ incubation. In some experiments, cells were pre-incubated for $15 \mathrm{~min}(\alpha-\mathrm{SMA}$ and F-actin expression, $\mathrm{Ca}^{2+}$ mobilisation and MLC phosphorylation) or $30 \mathrm{~min}$ (gel contraction) with B2R antagonist HOE140 $(1 \mu \mathrm{M})$ before exposure to BK. To evaluate the effect of $\mathrm{Ca}^{2+}$ chelator, cells were stimulated with $\mathrm{BK}$ for $60 \mathrm{~min}$ in medium containing EGTA.

The role of $\mathrm{Ca}^{2+} /$ calmodulin (CaM) and MLCK on BK-induced collagen gel contraction was investigated using the specific inhibitor of $\mathrm{Ca}^{2+} / \mathrm{CaM}$, W7 $(25 \mu \mathrm{M})$, and the inhibitor of MLCK, ML-7 (25 $\mu \mathrm{M})$.

In order to determine the effect of depleting influx of extracellular $\mathrm{Ca}^{2+}$ and efflux of $\mathrm{Ca}^{2+}$ stored on BK-induced $\mathrm{Ca}^{2+}$ mobilisation in HFL-1, cells were stimulated with BK $1 \mu \mathrm{M}$ in the presence of Ca-chelator EGTA $(5 \mathrm{mM})$ or were preincubated for $30 \mathrm{~min}$ with inositol-(1,4,5)-trisphosphate (IP3) receptor antagonist 2-amino-ethoxydiphenyl borate (2-APB; $200 \mu \mathrm{M})$ before stimulation with BK.

\section{Immunostaining for $\alpha$-SMA and F-actin}

For $\alpha$-SMA and F-actin organisation, human fetal lung fibroblasts were fixed in methanol at $-20^{\circ} \mathrm{C}$ and then stained with monoclonal mouse antibody against human $\alpha$-SMA (clone 1A4; Dako cytomation, Milan, Italy) or Texas Red-conjugated phalloidin (Sigma Aldrich S.r.l, Milan, Italy). Fluorescein isothiocyanateconjugate goat anti-mouse immunoglobulin G (Immunotech, Beckman Coulter Company, Milan, Italy) was used to visualise $\alpha$ SMA. Quantification of the myofibroblast number in each experimental condition was performed at $20 \times$ magnification, as previously described [16-18]. Only cells clearly showing positive staining for $\alpha$-SMA or F-actin were counted in a blinded manner in a minimum of three randomly chosen microscopic fields. The results were expressed as percentage of $\alpha$-SMA positive cells.

\section{Western blot analysis}

Electrophoresis of protein extracts and subsequent blotting were performed as previously described [18, 19]. Blots were incubated with a mouse anti- $\alpha$-SMA antibody (Dako cytomation), anti-MLC kinase antibody (Sigma), anti-MLC antibody (Sigma) or anti-diphospho-MLC (Thr-18/Ser-19; Santa Cruz Biotechnology, Santa Cruz, CA, USA) and visualised using the enhanced chemiluminescence system (Pierce Biotechnology, Inc., Rockford, IL, USA). Blots were re-probed with anti- $\beta$-actin antibodies (clone C4; Boehringer Mannheim, Inc., Mannheim, Germany). The relevant band intensities were quantified using a Versadoc Imaging System model 3000 (Biorad Laboratories, Inc., Hercules, CA, USA).

\section{Collagen gel contraction assay}

Collagen gel contraction assay was conducted as previously described [20]. Collagen gels were prepared by mixing the appropriate amount of rat tail tendon collagen, distilled water, four-times concentrated DMEM and cell suspensions. Aliquots $\left(500 \mu \mathrm{L} \cdot\right.$ well $\left.^{-1}\right)$ of the mixture were cast into each well of a $24-$ well tissue culture plate (Falcon; BD Becton Dickinson Italia, S.p.A, Milan, Italy) and allowed to gel. HFL-1 cells $\left(1.5 \times 10^{5}\right)$ were cultured in collagen gels for 5 days. After being washed, the collagen gels were released from the tissue culture plates and transferred into $60-\mathrm{mm}$ tissue culture dishes, which contained DMEM with or without designated reagents and incubated at $37^{\circ} \mathrm{C}$ under a $5 \% \quad \mathrm{CO}_{2}$ atmosphere for the indicated period. Various reagents were added before release or simultaneously with release as described separately. Gel size was measured using ImageJ (National Institute of Health, 
Bethesda, MD, USA). Data are expressed as the ratio of treated gel area to untreated gel area measured immediately after release.

\section{Fluorimetric determination of the $\left[\mathrm{Ca}^{2+}\right]_{i}$}

The fluorescent calcium indicator Fura-2 was used to determine the intracellular calcium concentration in human airway fibroblasts (HFL-1). HFL-1 fibroblasts $\left(2.5-3 \times 10^{4}\right)$ grown on 20-mm coverslips were incubated with $10 \mu \mathrm{M}$ Fura-2acetoxymethyl ester (Fluka, Milan, Italy) and Pluronic F-127 (Sigma) in medium for $45 \mathrm{~min}$ at $37^{\circ} \mathrm{C}$. After addition of known concentrations of bradykinin to the perfusion chamber, the time-course of the cytosolic calcium level was determined as described previously [21].

\section{Statistical analysis}

Statistical evaluation was performed using the statistical software package GraphPad Prism 3.0 (GraphPad Software, San Diego, CA, USA). Data are presented as mean \pm SEM. $\left[\mathrm{Ca}^{2+}\right]_{i}$ curve to BK was tested for significance by one-way ANOVA and post hoc Student Newman-Keuls test. A p-value $<0.05$ was considered to be significant.

\section{RESULTS}

Modulation of fibroblast-induced collagen-gel contraction In control gels containing unstimulated HFL-1 cells, a spontaneous and detectable contraction was observed over the entire experimental period, with a significant $\%$ decrease in area at $120 \mathrm{~min}(\mathrm{p}<0.05)$. At all the concentrations tested $(0.01 \mu \mathrm{M}, 0.1 \mu \mathrm{M}$ or $1 \mu \mathrm{M})$, BK induced a detectable increase in gel contraction, significantly after 60 and $120 \mathrm{~min}$ of incubation ( $p<0.01$, each comparison) (fig. 1a).

Pre-treatment of HFL-1 cells with the B2R antagonist HOE140 $(1.0 \mu \mathrm{M})$ or the addition of the $\mathrm{Ca}^{2+}$ chelator EGTA $(5.0 \mathrm{mM})$ to the culture medium before stimulation with submaximal concentration of BK $(0.1 \mu \mathrm{M})$ for $60 \mathrm{~min}$ provoked a $63 \%$ and $34 \%$ inhibition, respectively, of the BK-induced gel contraction $(p<0.05)$ (fig. 1b). In HFL-1 cells, BK-induced gel contraction was reduced by the specific inhibitor of calcium/CaM W7 $(25 \mu \mathrm{M})$ or the inhibitor of MLCK ML-7 $(25 \mu \mathrm{M})$ at $60 \mathrm{~min}(83 \%$ and $80 \%$ inhibition, respectively; $\mathrm{p}<0.0001$ ) (fig. 1c).

\section{Role of $\alpha-S M A$ in fibroblast-induced collagen-gel contraction}

To determine the role of $\alpha$-SMA in BK-induced HFL-1 gel contraction, siRNA targeted against $\alpha$-SMA (si $\alpha$-SMA) was used to suppress $\alpha$-SMA expression in both unstimulated and BK-treated cells (fig. 2a). Following si $\alpha$-SMA transfection, gel contraction assay was performed (fig. 2b). siRNA-untreated cells significantly augmented contraction of collagen gels in the presence of $\mathrm{BK}$ at $60 \mathrm{~min}$, while si $\alpha$-SMA-treated cells exhibited a significantly reduced contraction compared to siRNA-untreated cells in the presence of BK (fig. 2b).

\section{Upregulation of $\alpha$-SMA expression}

Western blot analysis demonstrated a weak constitutive $\alpha$-SMA protein expression by HFL-1 cells that was progressively upregulated by BK $(1 \mu \mathrm{M})$ from 5-60 min. Quantitative analysis demonstrated that the increase in protein expression was significant at each time-point tested ( $\mathrm{p}<0.001$, each comparison) (fig. 3a). Evaluation of HFL-1 fibroblasts by immunofluorescence
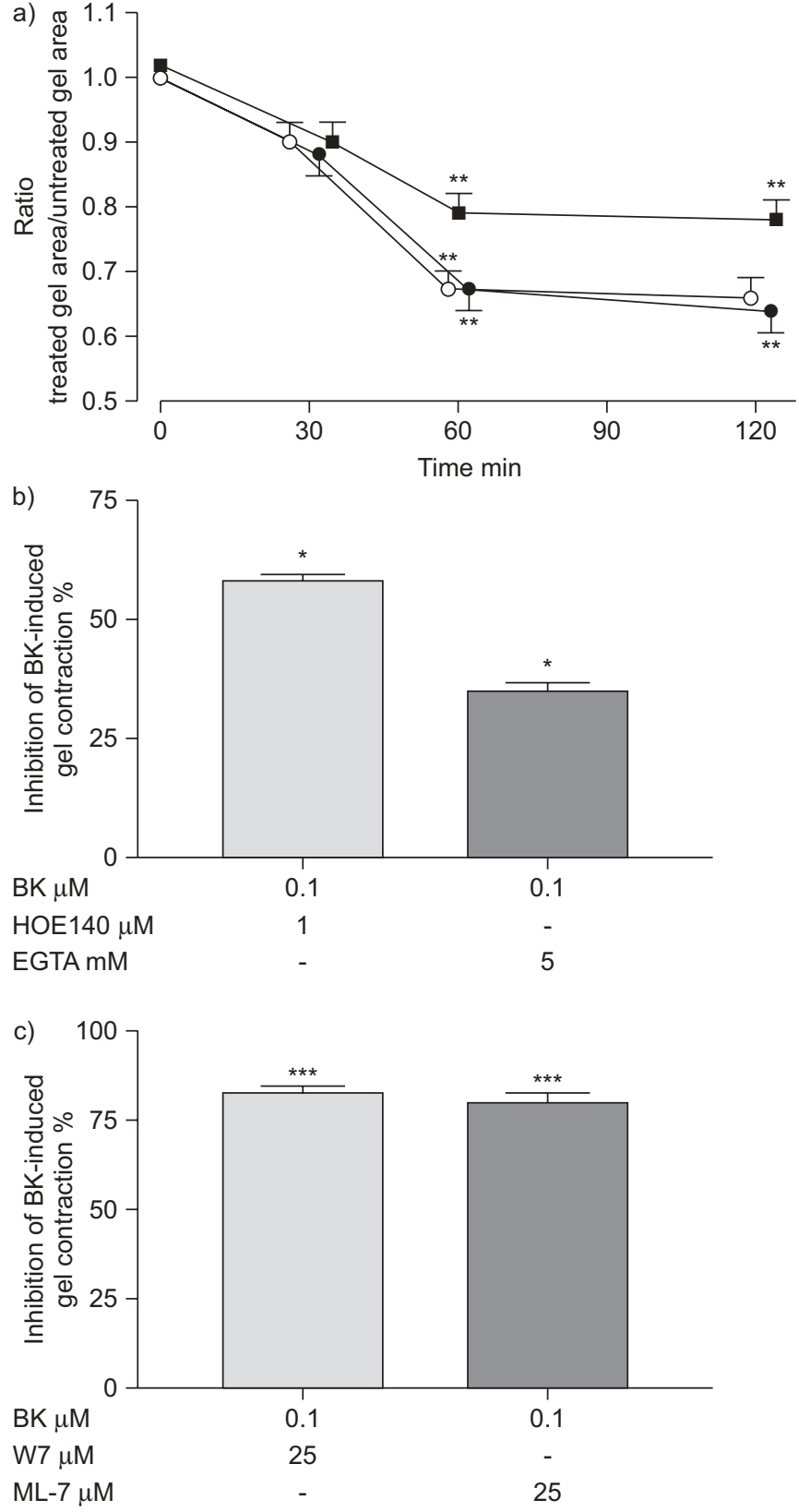

FIGURE 1. Bradykinin (BK) increased HFL-1 fibroblast-mediated contraction of collagen gel via BK B2 receptor (B2R)-Ca ${ }^{2+}$ calmodulin (CaM)/myosin light-chain kinase (MLCK)-dependent pathways. a) Time-dependent contraction of collagen gels by human fetal lung fibroblasts augmented by BK. $\mathbf{\square}$ : BK $0.01 \mu \mathrm{M}$; $\bigcirc$ : BK $0.1 \mu \mathrm{M}$; • : BK $1 \mu \mathrm{M}$. b) Effects of B2R antagonist HOE140 and $\mathrm{Ca}^{2+}$ chelator EGTA on BK-induced fibroblast-mediated gel contraction. c) Effects of specific inhibitor of calcium/CaM W7 and the inhibitor of MLCK ML-7 on BK-induced fibroblastmediated gel contraction. b, c) The area of gels was measured after 60 min incubation with BK $(0.1 \mu \mathrm{M})$. Data are presented as mean \pm SEM from three independent experiments. $* *: p<0.01$ versus unstimulated cells; $*$ : $p<0.05$ and $\star * *: p<0.001$ versus HFL-1 fibroblasts stimulated with BK.

showed that the BK-induced enhancement of $\alpha$-SMA protein expression was due to a significant increase in the number of $\alpha-\mathrm{SMA}^{+}$cells (fig. $3 \mathrm{~b}$ ) and, furthermore, to a timely progressive polymerisation of $\alpha-\mathrm{SMA}^{+}$stress fibres (fig. 3b). Similarly, 

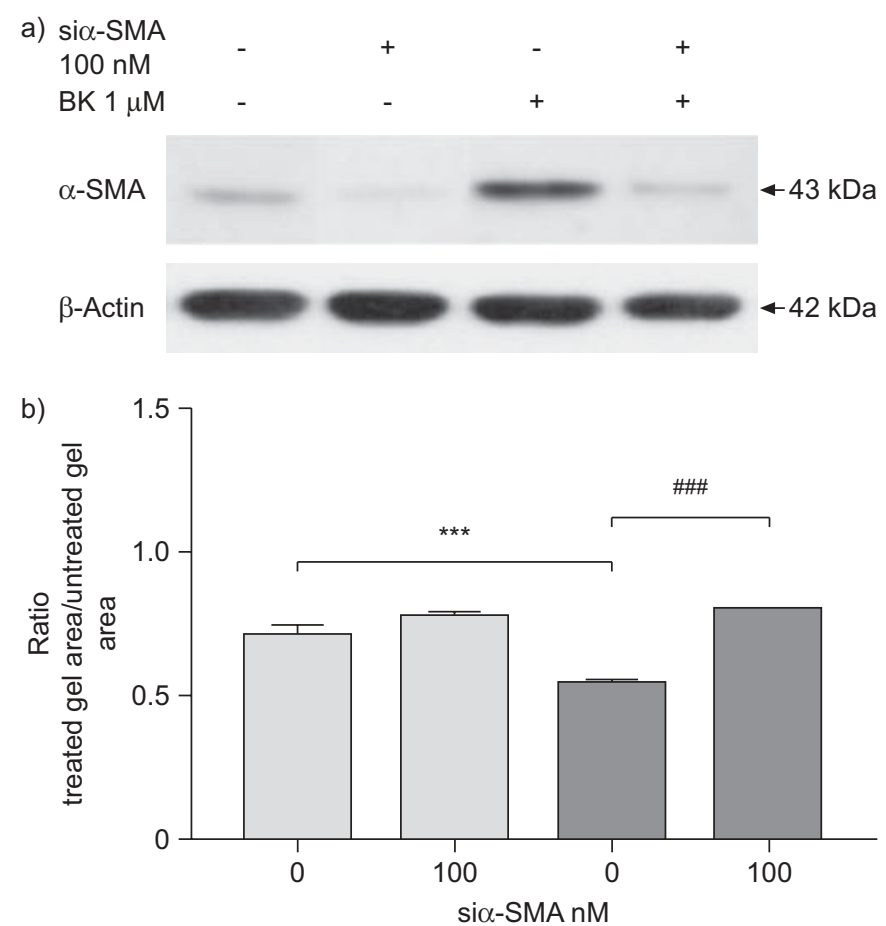

FIGURE 2. Role of $\alpha$-smooth muscle actin ( $\alpha$-SMA) in bradykinin (BK)-induced HFL-1 fibroblast-mediated collagen gel contraction. a) Expression of $\alpha$-SMA protein in HFL-1 cells after $\alpha$-SMA-small interfering RNA (siRNA). $\beta$-Actin antibody was used to demonstrate equal protein loading. Data are presented from one of three similar experiments with similar results. b) Effect of $\alpha$-SMA-siRNA on collagen gel contraction. a: no BK; $\mathbf{m}:$ BK $0.1 \mu \mathrm{M}$. The data are presented as mean \pm SEM from three independent experiments. ${ }^{* * *}: \mathrm{p}<0.001$ versus unstimulated cells; ${ }^{\# \# \#: ~} \mathrm{p}<0.001$ versus si $\alpha$-SMA untreated HFL-1 fibroblasts stimulated with BK.

rhodamine-phalloidin staining showed a BK-induced increase in the number of F-actin ${ }^{+}$cells and in the polymerisation F-actin ${ }^{+}$ stress fibres (fig. 3b). Pre-treatment of HFL-1 cells with HOE140 or the addition of EGTA to the culture medium before stimulation with BK for 60 min provoked a $25 \%$ inhibition and a complete inhibition, respectively, of the BK-induced $\alpha$-SMA expression ( $<<0.01$, each comparison) (fig. 4a), in conjunction with a reduction in the number of $\alpha-\mathrm{SMA}^{+}$cells and in the organisation of $\alpha$-SMA cytoskeletal filaments (fig. $4 \mathrm{~b}$ ). Rhodamine-phalloidin staining showed similar results (fig. $4 b$ ).

\section{Calcium mobilisation of $\left[\mathrm{Ca}^{2+}\right]_{i}$ from extracellular compartment}

In the presence of extracellular $\mathrm{Ca}^{2+}\left(\mathrm{CaCl}_{2} 1.8 \mathrm{mM}\right)$, the resting levels of intracellular $\mathrm{Ca}^{2+}$ concentration $\left[\mathrm{Ca}^{2+}\right]_{\mathrm{i}}$ in unstimulated HFL-1 $(23 \pm 1 \mathrm{nM})$ were increased in a concentration-dependent fashion by BK: $0.001 \mu \mathrm{M}$ : $42.5 \pm 7.5 \mathrm{nM}$; $0.01 \mu \mathrm{M} ; 105.3 \pm 18.2 \mathrm{nM} ; 0.1 \mu \mathrm{M} ; 234.3 \pm 12.5 \mathrm{nM}$; and $1 \mu \mathrm{M}$; $359.5 \pm 15.8 \mathrm{nM}$, respectively (fig. $5 \mathrm{a}$ ). As shown in figure $5 \mathrm{~b}$, in the presence of extracellular $\mathrm{Ca}^{2+}\left(\mathrm{CaCl}_{2} 1.8 \mathrm{mM}\right)$, the addition of BK $(1 \mu \mathrm{M})$ to the Fura-2-loaded cells led to a fast transient rise in $\left[\mathrm{Ca}^{2+}\right]_{i}$ that reached a peak (BK $1 \mu \mathrm{M}$ : $360 \pm 16 \mathrm{nM}$ ) within $15 \mathrm{~s}$ and tended to decrease to the resting level within $1 \mathrm{~min}$.

When HFL-1 cells were pre-incubated for $15 \mathrm{~min}$ with HOE140, the size of the BK-induced $\left[\mathrm{Ca}^{2+}\right]_{i}$ was markedly reduced in comparison to untreated HFL-1 (BK $1 \mu \mathrm{M}+\mathrm{HOE} 140: 80 \pm 35 \mathrm{nM}$; BK: $360 \pm 16 \mathrm{nM}$; p <0.01) (fig. 6a). In HOE140 pre-treated HFL-1, a BK-elicited $\left[\mathrm{Ca}^{2+}\right]_{i}$ raise was characterised by slower time-courses and smaller peak values compared to untreated cells (fig. 6b). Since the increase of intracellular calcium can be due to influx of extracellular calcium or release of calcium from intracellular stores via the IP3 receptor, we tested the calcium signalling in the presence or absence of extracellular calcium and/or of the IP3 receptor antagonist 2-APB. As shown in figure $6 \mathrm{c}$ (tracing 2), a BKinduced $\left[\mathrm{Ca}^{2+}\right]$ i increase was inhibited ( $34 \%$ inhibition) by pretreatment with 2 -APB in buffer containing $\mathrm{Ca}^{2+}(1.8 \mathrm{mM}$ $\mathrm{CaCl}_{2}$ ). When HFL-1 were exposed to BK in buffer $\mathrm{Ca}^{2+}$ free (0 mM CaCl $; 5 \mathrm{mM} \mathrm{EGTA),} \mathrm{a} \mathrm{dramatic} \mathrm{decrease} \mathrm{(64 \%}$ inhibition) of calcium peak was observed (fig. 6c, tracing 3). Exposure of HFL-1 to BK in the presence of 2-APB in $\mathrm{Ca}^{2+}$-free medium $\left(\mathrm{CaCl}_{2} 0 \mathrm{M}\right.$, EGTA $\left.5 \mathrm{mM}\right)$ resulted in an almost complete abolition of $\mathrm{Ca}^{2+}$ mobilisation (fig. $6 \mathrm{c}$, tracing 4).

\section{MLC phosphorylation and MLCK expression}

MLC phosphorylation was evaluated by Western blotting using an antibody against the phosphorylated Thr-18 and Ser19 residues. BK $(1 \mu \mathrm{M})$ induced time-dependent Thr-18/Ser-19 phosphorylation, which was detectable after $5 \mathrm{~min}$ and was progressively sustained for $60 \mathrm{~min}$ (fig. 7a).

Pre-treatment of HFL-1 cells with HOE140 or the addition of EGTA to the culture medium before stimulation with BK for $60 \mathrm{~min}$ provoked a $54 \% \quad(\mathrm{p}<0.05)$ and a $38 \% \quad(\mathrm{p}<0.01)$ inhibition of the BK-induced MLC phosphorylation, respectively (fig. $7 b$ ).

Because spatial and temporal pattern of MLC phosporylation in fibroblasts is controlled by MLCK, the possibility that BK could modulate MLCK expression was evaluated. However, Western blotting studies did not demonstrate any modification of the endogenous MLCK expression in HFL-1 cells stimulated with BK for a specified period (fig. 8).

\section{DISCUSSION}

Our study demonstrates that BK-induced fibroblast-mediated contraction of three-dimensional collagen gels is associated with simultaneous upregulation $\alpha$-SMA expression and polymerisation of $\alpha$-SMA stress fibres, and involves the $\mathrm{Ca}^{2+} / \mathrm{CaM}$ MLCK pathway with MLC phosphorylation. The effects of BK on fibroblasts were dependent on the increase of $\left[\mathrm{Ca}^{2+}\right]_{i}$ concentrations, mainly derived from the extracellular compartment, and appeared to be mediated by the B2R, because the selective B2R antagonist attenuated the fibroblast responses.

BK, a classical mediator of acute inflammation, has been proposed as a putative pathogenetic component contributing to reversible airway obstruction in asthma because it affects vascular tone and permeability, increases secretion of mucus, contracts smooth muscle cells and provokes airway hyperresponsiveness [7, 8]. BK may be also involved in tissue fibrotic changes because of its ability to induce lung fibroblast activation, proliferation, differentiation and contraction through a variety of intracellular signals $[9,15,20]$. Peribronchial fibrosis, a feature of asthma, may lead to the narrowing of small airways and could contribute to the fixed airflow limitation that compromises respiratory function [22]. Fibroblasts are known 
$\begin{array}{lllllll}\text { a) BK } 1 \mu \mathrm{M} & - & + & + & + & + \\ \text { Time min } & 0 & 5 & 15 & 30 & 60 \\ \alpha \text {-SMA } & & & \\ \beta & \end{array}$

c)
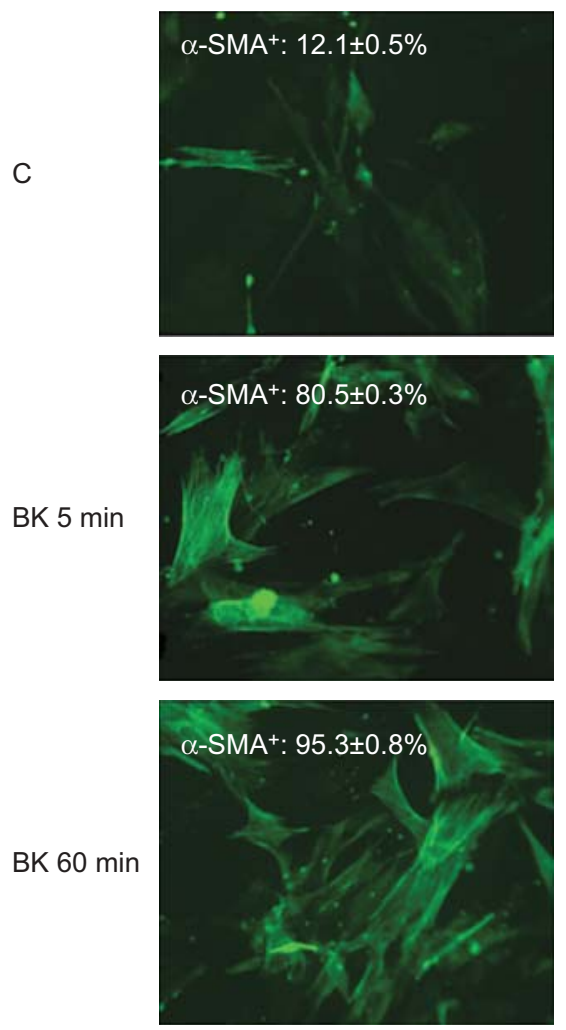

$\alpha-S M A$
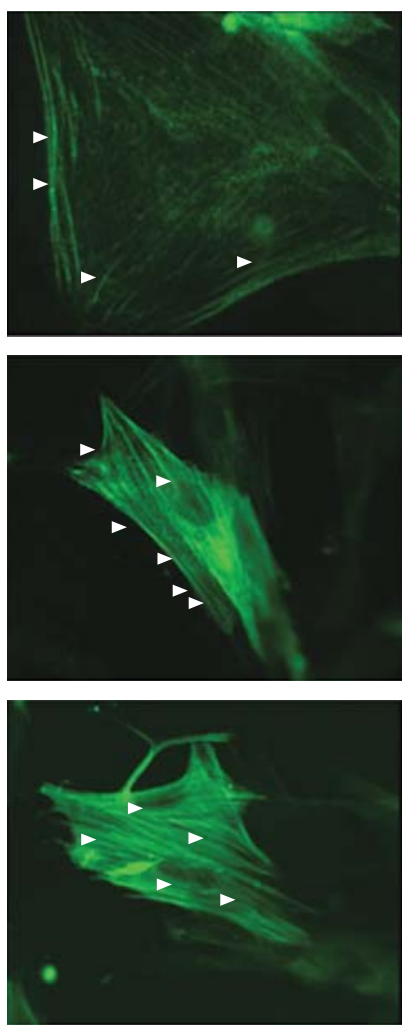

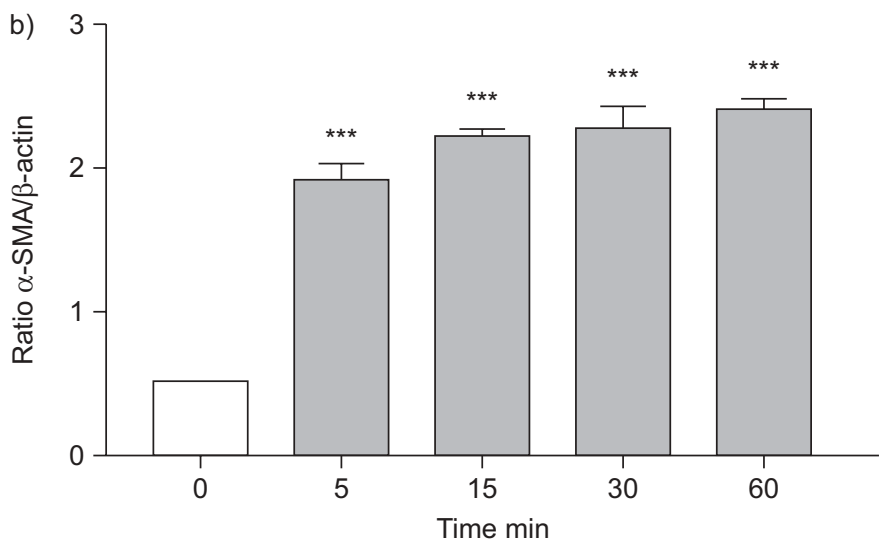

Phalloidin
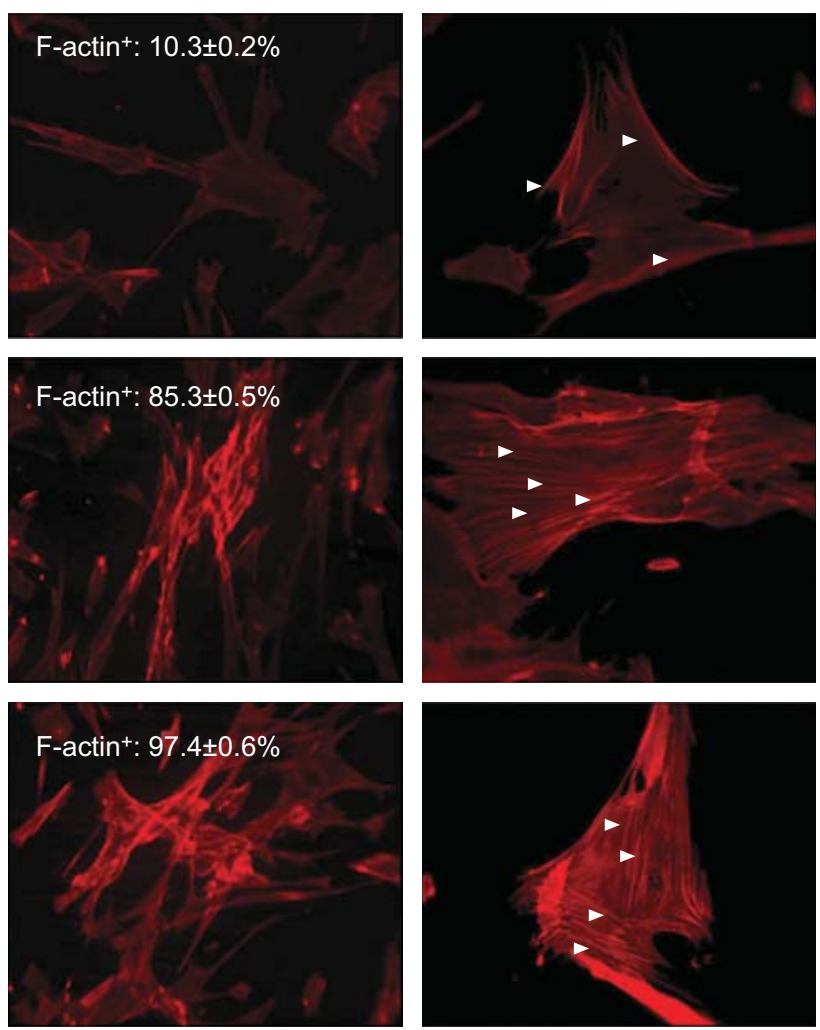

FIGURE 3. Effect of bradykinin (BK) on myofibroblast differentiation. Time-dependent a) $\alpha$-smooth muscle actin ( $\alpha$-SMA) protein expression and b) $\alpha$-SMA ${ }^{+}$and F-actin ${ }^{+}$ cells and $\alpha$-SMA and F-actin polymerisation induced by BK in HFL-1 fibroblasts. Unstimulated cells were used as a negative control (C). a) Representative blotting for $\alpha$-SMA and $\beta$-actin are shown from one of three experiments which gave similar results. b) After densitometric analysis data were normalised to $\beta$-actin and plotted as mean \pm SEM c) The arrowheads indicate the polymerisation of $\alpha-\mathrm{SMA}^{+}$and F-actin ${ }^{+}$stress fibres. The results shown are representative of three independent experiments. $\square$ : BK $1 \mu \mathrm{M}$. ***: $p<0.001$ versus unstimulated cells.

not only to participate in tissue rearrangement through the deposition of increased amounts of collagen (especially type III and V), fibronectin and polysaccharides (such as hyaluronic acid), but also to generate traction forces [23], as also shown in our study.

When cultured in a gel composed of a native-collagen threedimensional system, fibroblasts attach to the collagen fibres and spontaneously generate traction forces that result in gel contraction. This function may be increased by a variety of mediators, including platelet-derived growth factor and transforming growth factor- $\beta$, and downregulated by $\beta$ adrenergic agonists and prostaglandin $E_{2}[24,25]$. In agreement with a previous observation, we found that a significant increase in BK-induced fibroblast-mediated collagen-gel contraction is detectable at $\mathrm{BK}$ concentrations similar to those found in human sputum [26] and after a relatively short period of time (60 $\mathrm{min})$ [15]. Using siRNA technology, we also demonstrated the involvement of $\alpha$-SMA in BK-induced collagen gel contraction [16]. Blockade of $\alpha$-SMA expression 


\begin{tabular}{|c|c|c|c|c|c|}
\hline BK $1 \mu \mathrm{M}$ & - & + & + & + & \\
\hline HOE140 $\mu \mathrm{M}$ & - & - & 1 & - & \\
\hline EGTA mM & - & - & - & 5 & \\
\hline$\alpha$-SMA & 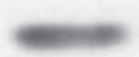 & & $2=0$ & $=$ & $443 \mathrm{kDa}$ \\
\hline$\beta$-Actin & & & & & ४ $42 \mathrm{kDa}$ \\
\hline
\end{tabular}

c)

BK

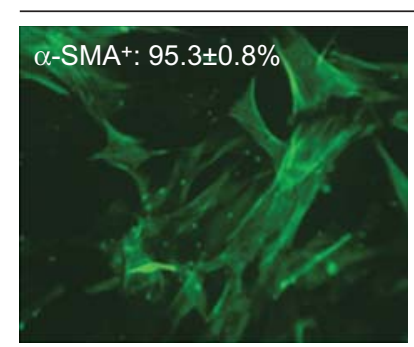

$\alpha-S M A$
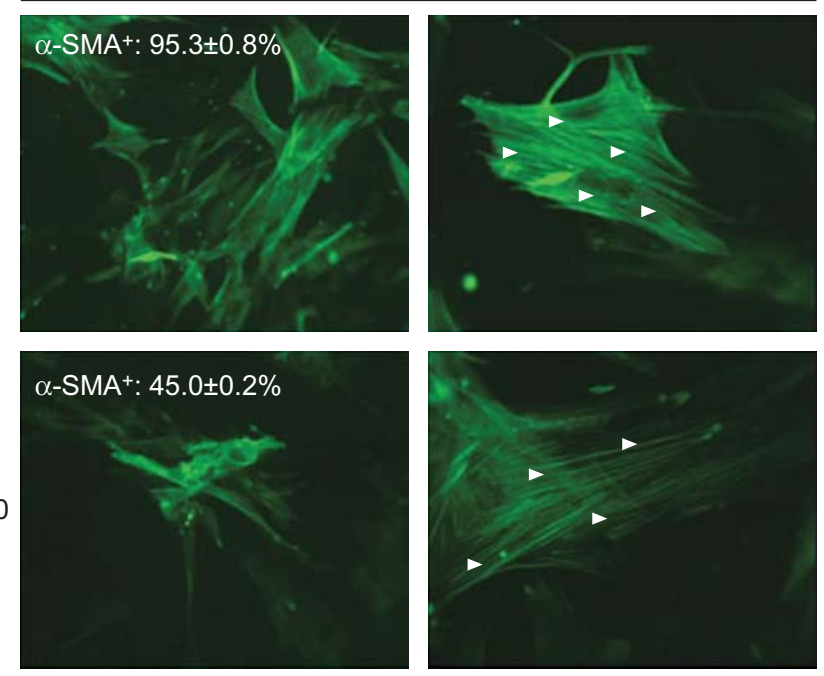

$\mathrm{BK}+\mathrm{HOE} 140$

$B K+E G T A$
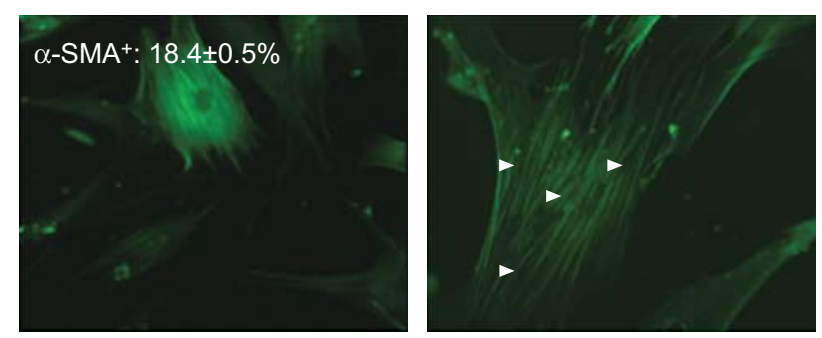

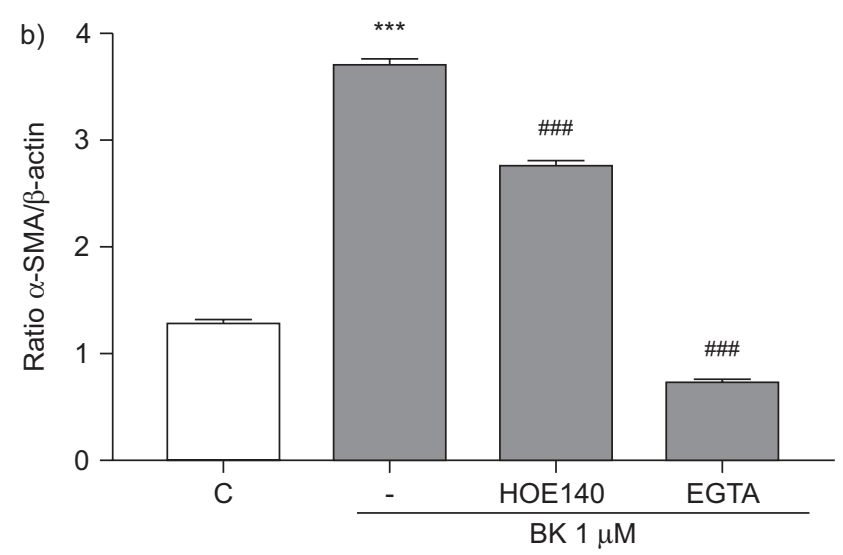

Phalloidin
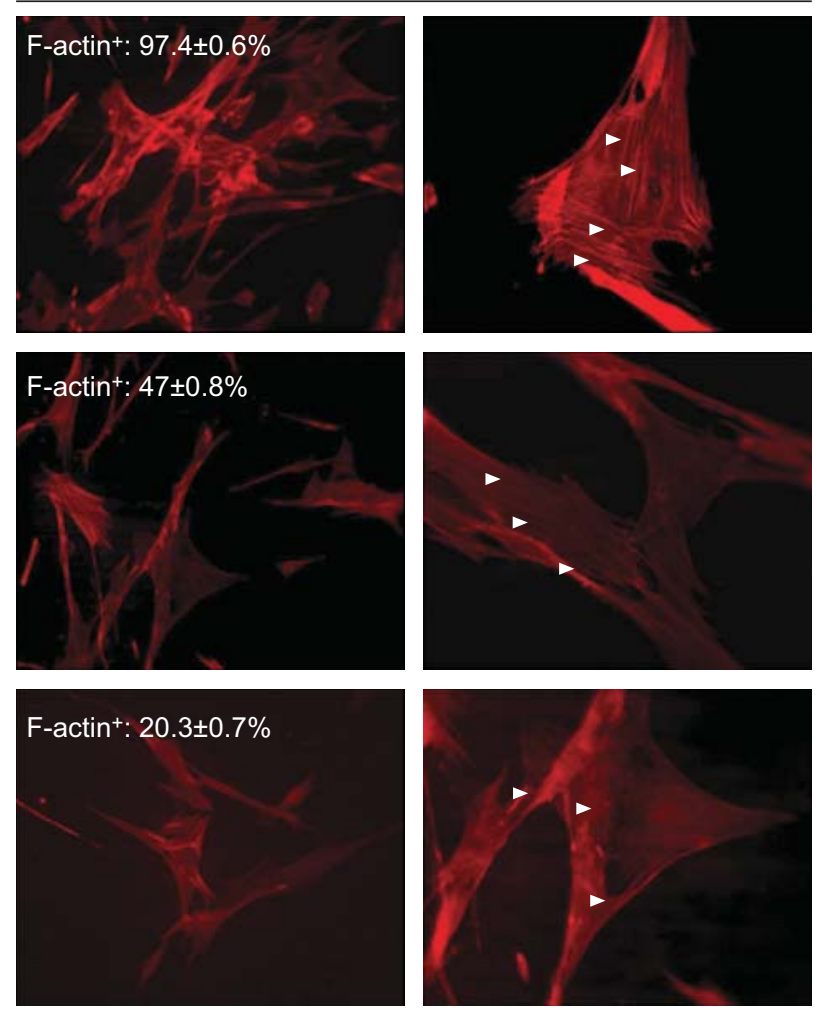

FIGURE 4. Effect of bradykinin (BK) on myofibroblast differentiation. Effects of BK B2 receptor antagonist HOE140 or the Ca ${ }^{2+}$ chelator EGTA on a) BK-induced $\alpha$ smooth muscle action ( $\alpha$-SMA) protein expression and b) $\alpha$-SMA ${ }^{+}$and F-actin ${ }^{+}$cells and $\alpha$-SMA and F-actin polymerisation in HFL-1. a) Representative blotting for $\alpha$-SMA and $\beta$-actin are shown from one of three experiments which gave similar results. b) After densitometric analysis data were normalised to $\beta$-actin and plotted as mean \pm SEM. C) The arrowheads indicate the polymerisation of $\alpha-\mathrm{SMA}^{+}$and $\mathrm{F}$-actin ${ }^{+}$stress fibres. The results shown are representative of three independent experiments. C: control. $* * *: p<0.001$ versus unstimulated cells; ${ }^{\# \# \#: ~} p<0.001$ versus HFL-1 fibroblasts stimulated with BK without treatment with HOE140 or EGTA.

prevented the increase in collagen gel contraction that was observed in HFL-1 after BK stimulation.

A previous study by VANCHERI et al. [9] demonstrated that BK induced the expression of $\alpha$-SMA in normal human lung fibroblasts after $48-72 \mathrm{~h}$. However, the ability of BK in modulating myofibroblast differention at earlier time-points has never been studied. Importantly, using Western blot analysis, we observed, for the first time, an early enhancement of the expression of $\alpha$-SMA in the presence of BK, which was significant after only $5 \mathrm{~min}$ of incubation. Our study did not investigate the intimate mechanisms behind $\alpha$-SMA protein expression, but we may speculate that the modulation of $\alpha$ SMA protein expression by BK is probably sustained by posttranslational mechanisms rather than a de novo protein synthesis within $5 \mathrm{~min}$ [27]. All actin isoforms, including $\alpha$ SMA, are present in cells in a monomeric (G-actin) or a polymeric state (filamentous or F-actin). F-actin is generally organised into three discrete structures: actin stress fibres, lamellipodia and filopodia [2, 10]. Organised in an F-actin isoform and mainly into stress fibres, as shown here, $\alpha$-SMA promotes myofibroblast contractility [10]. Analysis of $\alpha$-SMA 

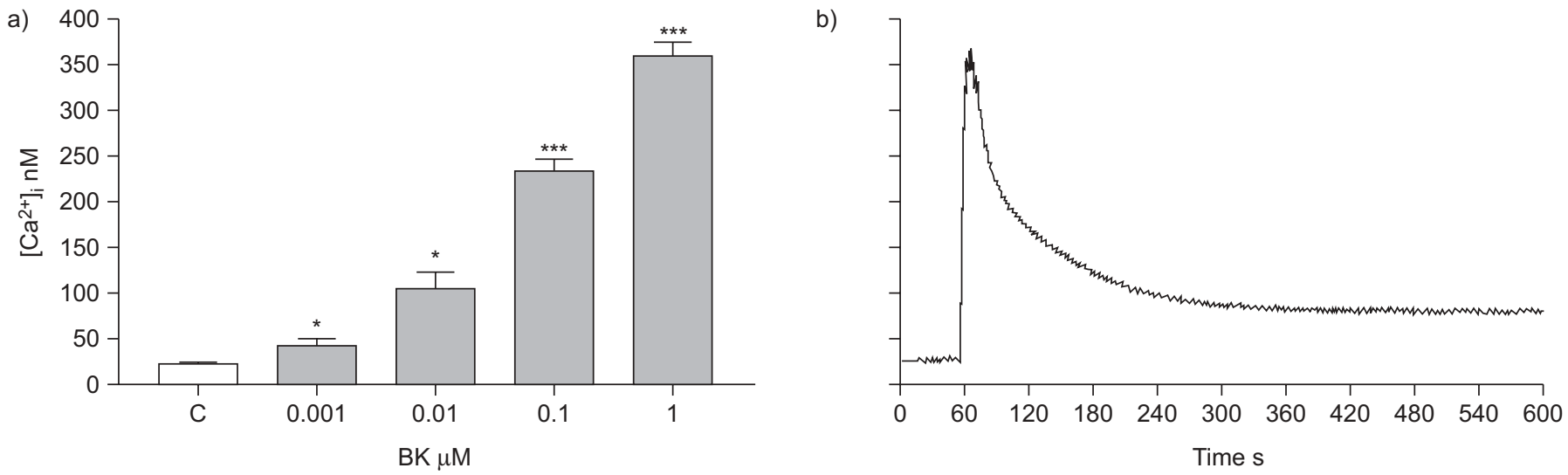

FIGURE 5. Bradykinin (BK) induced $\mathrm{Ca}^{2+}$ mobilisation in HFL-1. a) Concentration-response curves of BK-induced intracellular $\mathrm{Ca}^{2+}$ concentration $\left(\left[\mathrm{Ca}^{2+}\right]_{i}\right)$ increase Fibroblasts were exposed to different concentration of $\mathrm{BK}$ and $\left[\mathrm{Ca}^{2+}\right]_{i}$ was measured as described in the Materials and methods section. Data are presented as mean \pm SEM from three independent experiments. C: control. *: $p<0.05$; ${ }^{* *}: p<0.001$ versus unstimulated HFL-1 fibroblasts. b) Representative tracing of the individual effect of BK on $\left[\mathrm{Ca}^{2+}\right]_{\text {. }}$. The arrow indicated where BK $1 \mu \mathrm{M}$ was added.

and F-actin by immunofluorescence in HFL-1 cells after BK treatment revealed that the enhancement of the number of $\alpha$ $\mathrm{SMA}^{+}$and $\mathrm{F}-$ actin $^{+}$cells was associated with a progressive polymerisation of $\alpha-\mathrm{SMA}^{+}$and $\mathrm{F}$-actin ${ }^{+}$stress fibres. The findings suggest that BK-induced fibroblast-mediated collagen gel contraction may be dependent on enhanced fibroblast differentiation into myofibroblast, with up-regulation of $\alpha$ SMA protein expression and its progressive polymerisation into stress fibres.
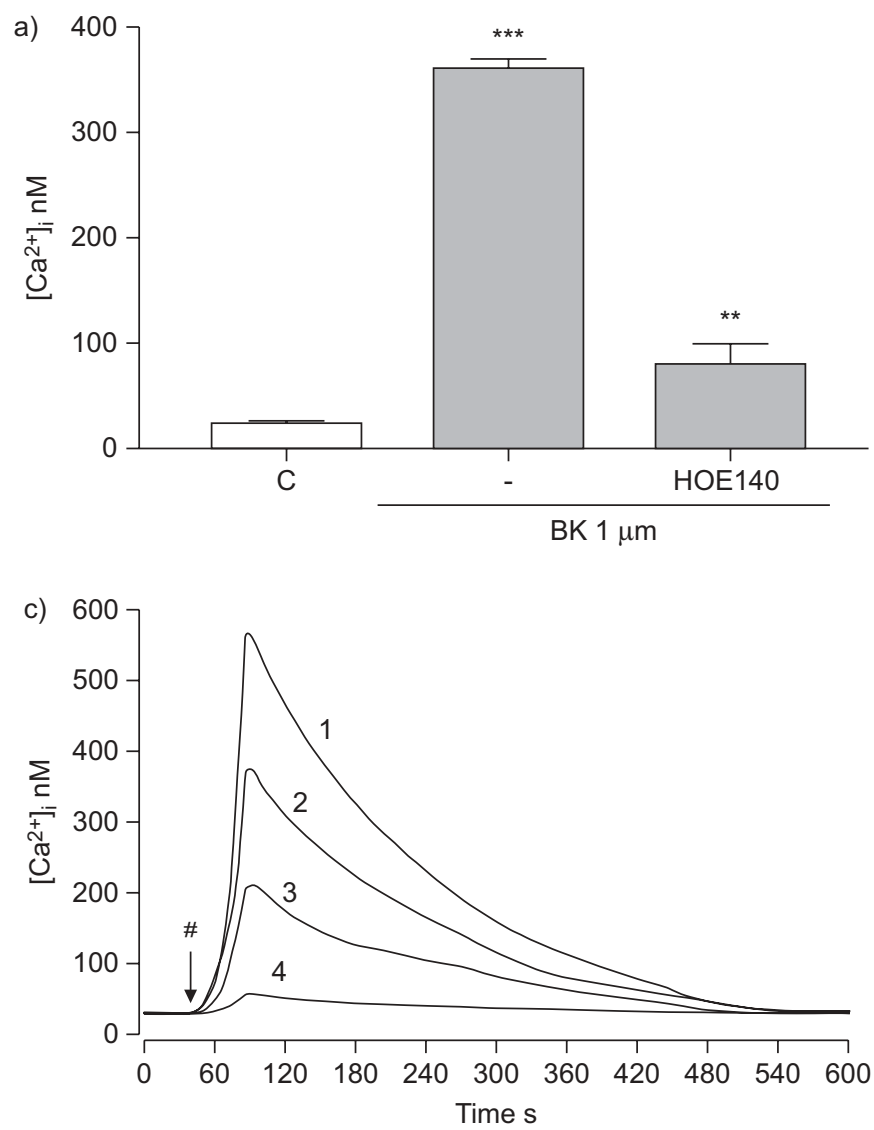

The capability of contractile cells to exert tractional force on the substratum is mainly due to the spatial and temporal pattern of MLC phosphorylation, regulated by the balance of two enzymatic activities, the MLC kinases and the MLC phosphatases [11, 28]. MLC kinases are activated by the $\mathrm{Ca}^{2+} / \mathrm{CaM}$ complex and catalyze myosin II regulatory light chain phosphorylation at two sites: Ser-19 and Thr-18. Phosphorylation at these sites is required for myosin II filament formation [26, 28, 29], myosin II interaction with F-actin and an increase in myosin

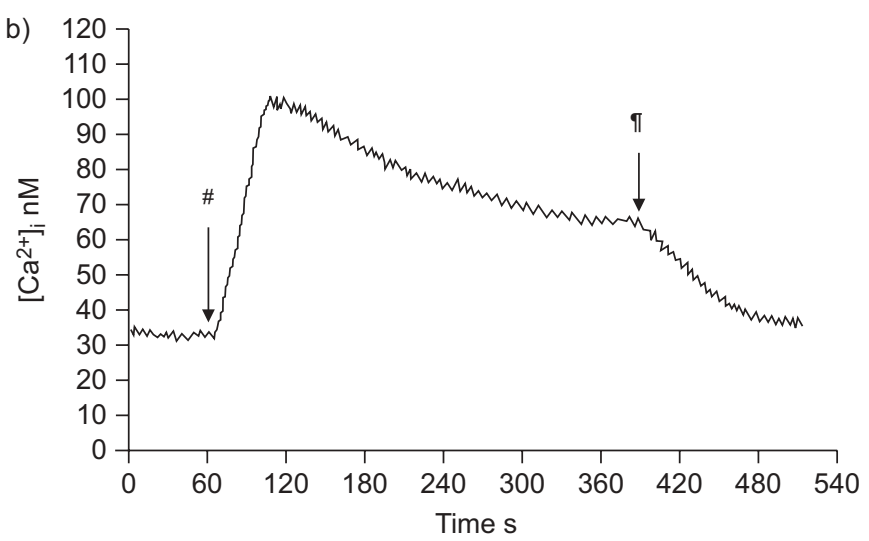

FIGURE 6. Bradykinin (BK) induced $\mathrm{Ca}^{2+}$ influx via BK B2 receptor (B2R) in HFL-1. a) Effect of the selective B2R antagonist (HOE140) on $\mathrm{Ca}^{2+}$ mobilisation (intracellular $\mathrm{Ca}^{2+}$ concentration $\left(\left[\mathrm{Ca}^{2+}\right]_{\mathrm{i}}\right)$ ) in HFL-1. Data are presented as mean \pm SEM from three independent experiments. C: control. ${ }^{* *}: p<0.01$ versus HFL-1 fibroblasts stimulated with BK. ${ }^{* * *}: p<0.001$ versus unstimulated cells. b) Representative tracing of the individual effect of $\mathrm{BK}$ on $\left[\mathrm{Ca}^{2+}\right]_{\mathrm{i}}$ in $\mathrm{HFL}-1$ preincubated with HOE140 (1 $\mu \mathrm{M})$ for 15 min before exposure to BK. c) Effect of EGTA and/or 2-amino-ethoxydiphenyl borate (2-APB) on BK-stimulated changes in $\left[\mathrm{Ca}^{2+}\right]_{\mathrm{i}} .1$ and 2: cells were stimulated by $\mathrm{BK}$ in the absence or presence of 2-APB, respectively, to the buffer containing $\mathrm{Ca}^{2+}\left(1.8 \mathrm{mM} \mathrm{CaCl}_{2}\right) ; 3$ and 4: BK was added to buffer $\mathrm{Ca}^{2+}$-free $(0 \mathrm{mM} \mathrm{CaCl} ; 5 \mathrm{mM}$ EGTA) in the absence or presence of 2-APB, respectively. The traces shown are typical of three separate experiments. ${ }^{\#}$ : introduction of $\mathrm{BK} 1 \mu \mathrm{M} ;{ }^{\circ}$ : wash. 


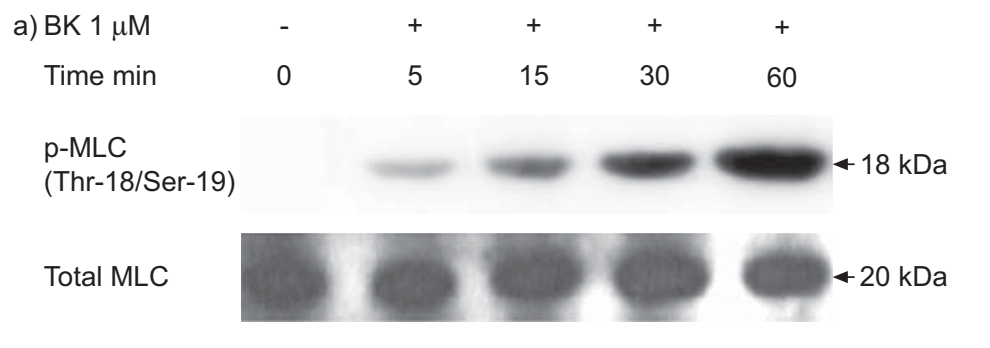

(1)

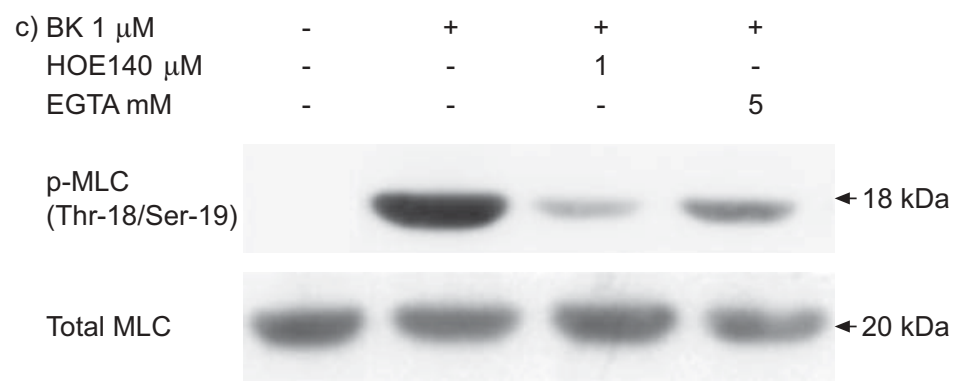

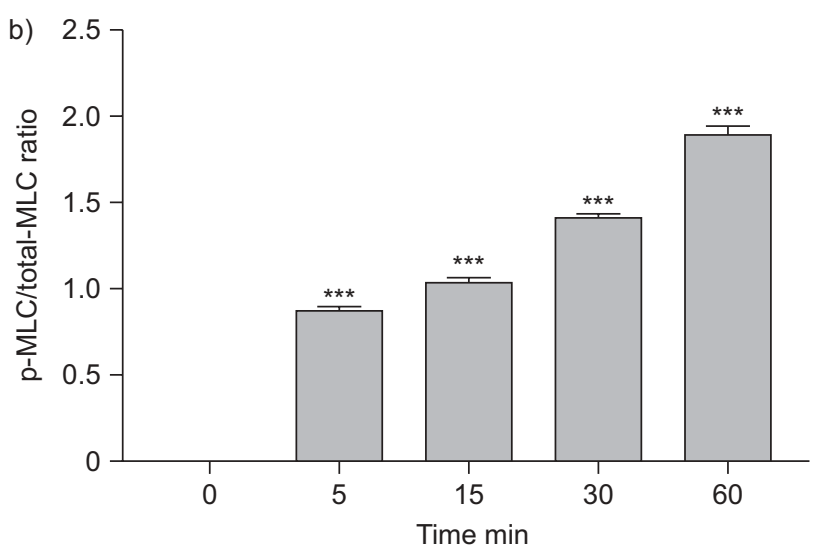

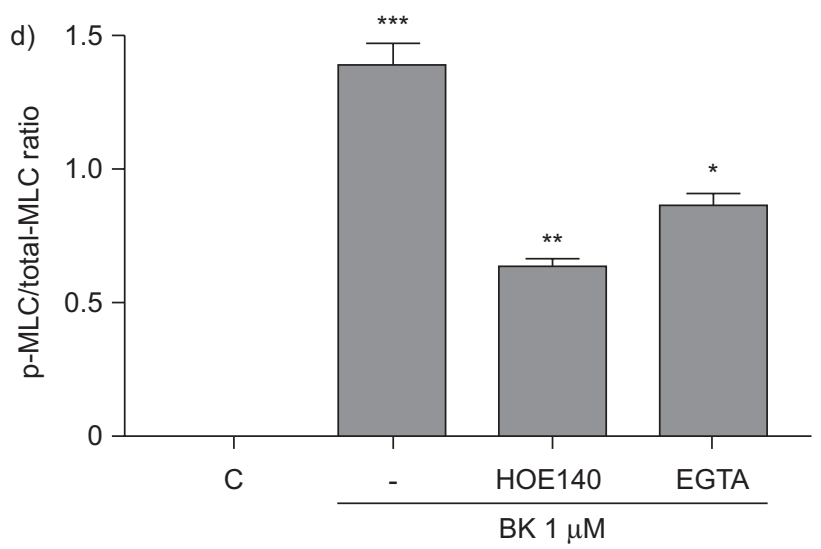

FIGURE 7. Bradykinin (BK) induced myosin light-chain (MLC) phosphorylation via $\mathrm{Ca}^{2+}$-calmodulin/MLC kinase-dependent pathways in HFL-1 fibroblasts. a, b) Timedependent MLC phosphorylation by BK in HFL-1 fibroblasts. Unstimulated cells were used as a negative control (C). c, d) Effects of BK B2 receptor antagonist HOE140 or the $\mathrm{Ca}^{2+}$ chelator EGTA on BK-enhanced MLC phosphorylation in HFL-1. Total cell lysates containing $40 \mu \mathrm{g}$ protein were prepared and assayed for diphosphorylated (Thr-18/ Ser-19) MLC (p-MLC) and total MLC expression by immunoblot analysis as described in the Materials and methods section. a, c) Representative blotting for p-MLC and total MLC are shown from one of three experiments which gave similar results. b, d) After densitometric analysis data were normalised to total MLC and plotted as mean \pm SEM. I. : BK $1 \mu \mathrm{M} .{ }^{*}: \mathrm{p}<0.05,{ }^{* *}: \mathrm{p}<0.01$ versus HFL-1 fibroblasts stimulated with BK without treatment with HOE140 or EGTA. ***: $\mathrm{p}<0.001$ versus unstimulated cells.

II ATPase activity. These phosphorylation-driven events are essential for initiation and maintenance of myosin II-based contraction [23]. We also showed that BK-induced fibroblastmediated collagen-gel contraction is associated with MLC activation, as demonstrated by the strong inhibition of BKinduced gel contraction in the presence of the specific inhibitor calcium/CaM and the inhibitor of MLCK [30], and by the BKincreased Thr-18/Ser-19 phosphorylation of MLC. These results are consistent with previous studies showing that MLC phosphorylation in smooth muscle cells takes the order of minute when evaluated by Western blotting [31] and is in order of millisecond when studied by photolysis [32]. No modifications of MLCK expression occurred in our experimental system, suggesting that total MLCK content may have almost no influence on the BK-induced $\mathrm{Ca}^{2+} / \mathrm{CaM}$ in human fetal lung fibroblast contraction.

Human fibroblasts, including the human fetal lung fibroblast cell line used in our study, express the B2R [15]. B2R is involved not only in fibroblast differentiation but also in their contraction and in MLC phosphorylation, as demonstrated in our study. Indeed, pre-incubation of the cells with the specific B2R antagonist HOE140 significantly inhibited all three responses.
B2R acts through the activation of $G$ proteins that stimulate the activity of phospholipase C. This results in phosphatidylinositol turnover and in a transient increase concentration of $\left[\mathrm{Ca}^{2+}\right]_{\mathrm{i}}$, through $\mathrm{Ca}^{2+}$ influx from the extracellular space and/ or $\mathrm{Ca}^{2+}$ release from sequestered internal store $[15,33]$. Exposure to BK increases $\left[\mathrm{Ca}^{2+}\right]_{\mathrm{i}}$ levels in different cell types, including tracheal epithelial and mouse fibroblasts [34]. Our study also shows that BK-activation of human fetal lung fibroblasts was associated with a concentration-dependent rapid increase in $\left[\mathrm{Ca}^{2+}\right]_{\mathrm{i}}$ levels, kinetically supporting its involvement in the fast MLCK activation. The instantaneous, linear and transient rise in $\left[\mathrm{Ca}^{2+}\right]_{i}$ was partly inhibited by the specific B2R antagonist HOE140 and by the IP3 receptor antagonist 2-APB. In contrast, a more dramatic inhibition of calcium peak was observed in HFL-1 stimulated by BK in buffer containing $\left[\mathrm{Ca}^{2+}\right]_{\mathrm{i}}$ chelator EGTA, suggesting that in fibroblast/myofibroblast extracellular calcium is more important for BK-induced calcium mobilisation than $\mathrm{Ca}^{2+}$ influx through the release from intracellular stores. The BK-induced expression of $\alpha$-SMA and its polymerisation stress fibres were also completely abolished by EGTA, while MLC phosphorylation and collagen-gel contraction were partly inhibited by EGTA. These results are not unexpected findings considering 

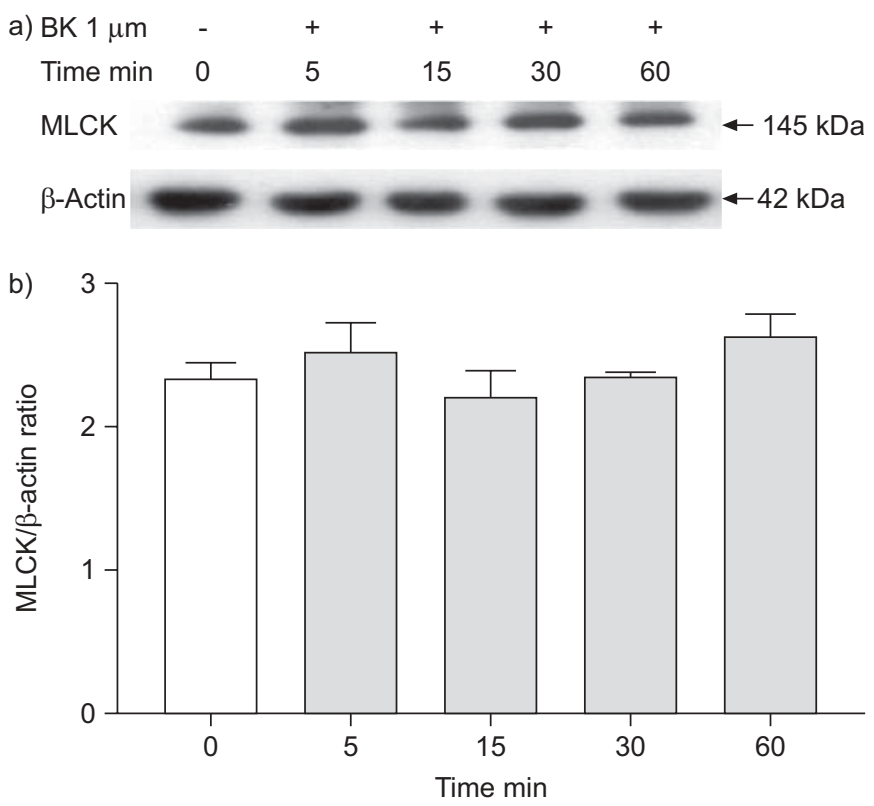

FIGURE 8. Effect of bradykinin (BK) on myosin light-chain kinase (MLCK) expression in HFL-1 fibroblasts. Cells were stimulated with BK $1 \mu \mathrm{M}$ for $5,15,30$ or $60 \mathrm{~min}(\square)$ and unstimulated cells were used as negative control $(\square)$. Total cell lysates containing $40 \mu \mathrm{g}$ protein were prepared and assayed for MLCK expression by immunoblot analysis as described in the Materials and methods section. a) Representative blotting for MLCK and $\beta$-actin is shown from one of three experiments which gave similar results. b) After densitometric analysis data were normalised to $\beta$-actin and plotted as mean \pm SEM.

the complexity of the different intracellular pathways involved in fibroblast activation $[15,20,25]$.

In conclusion, the current study demonstrated that the increased fibroblast-mediated collagen-gel contraction observed in the presence of $\mathrm{BK}$ is associated with an enhanced cell differentiation into $\alpha-\mathrm{SMA}^{+}$myofibroblasts, mediated through the activation of the B2R and involves a $\left[\mathrm{Ca}^{2+}\right]_{\mathrm{i}}$ dependent phosphorylated MLC pathway. However, further studies should be conducted to determine the effects of BK on human primary normal lung fibroblast cultures. The modulation of these processes by targeting BK receptors and/or the subsequent signalling pathway should be considered a novel area of research for reducing fibroblast-driven airway obstruction, possibly leading to new therapeutic horizons.

\section{SUPPORT STATEMENT}

This study was supported by the Italian Ministry of Health, Rome, Italy (grant Ricerca Corrente). The work was performed in the Pulmonary Disease Unit, G. Gaslini Institute, Genoa, Italy.

\section{STATEMENT OF INTEREST}

None declared.

\section{REFERENCES}

1 Leeb-Lundberg LM, Marceau F, Muller-Esterl W, et al. International Union of Pharmacology. XLV. Classification of the kinin receptor family: from molecular mechanisms to pathophysiological consequences. Pharmacol Rev 2005; 57: 27-77.
2 Regoli D, Barabe J. Pharmacology of bradykinin and related kinins. Pharmacol Rev 1980; 32: 1-46.

3 Greco S, Elia MG, Muscella A, et al. Bradykinin stimulates cell proliferation through an extracellular-regulated kinase 1 and 2dependent mechanism in breast cancer cells in primary culture. J Endocrinol 2005; 186: 291-301.

4 Marceau F. Kinin B1 receptors: a review. Immunopharmacology 1995; 30: 1-26.

5 Fox AJ, Barnes PJ, Urban L, et al. An in vitro study of the properties of single vagal afferents innervating guinea-pig airways. J Physiol 1993; 469: 21-35.

6 Bhoola KD, Bewley J, Crothers DM, et al. Kinin receptors on epithelial cells and smooth muscle of the trachea. Adv Exp Med Biol 1989; 247A: 421-427.

7 Ricciardolo FL, Geppetti P, Mistretta A, et al. Randomised doubleblind placebo-controlled study of the effect of inhibition of nitric oxide synthesis in bradykinin-induced asthma. Lancet 1996; 348: 374-377.

8 Trifilieff A, Da Silva A, Gies JP. Kinins and respiratory tract diseases. Eur Respir J 1993; 6: 576-587.

9 Vancheri C, Gili E, Failla M, et al. Bradykinin differentiates human lung fibroblasts to a myofibroblast phenotype via the B2 receptor. J Allergy Clin Immunol 2005; 116: 1242-1248.

10 Bogatkevich GS, Tourkina E, Abrams CS, et al. Contractile activity and smooth muscle $\alpha$-actin organization in thrombin-induced human lung myofibroblasts. Am J Physiol Lung Cell Mol Physiol 2003; 285: L334-L343.

11 Katoh K, Kano Y, Amano M, et al. Stress fiber organization regulated by MLCK and Rho-kinase in cultured human fibroblasts. Am J Physiol Cell Physiol 2001; 280: C1669-C1679.

12 Fajmut A, Brumen M. MLC-kinase/phosphatase control of $\mathrm{Ca}^{2+}$ signal transduction in airway smooth muscles. J Theor Biol 2008; 252: 474-481.

13 Obara K, Nikcevic G, Pestic L, et al. Fibroblast contractility without an increase in basal myosin light chain phosphorylation in wild type cells and cells expressing the catalytic domain of myosin light chain kinase. J Biol Chem 1995; 270: 18734-18737.

14 Brozovich FV. Rho signaling: agonist stimulation and depolarization come together. Circ Res 2003; 93: 481-483.

15 Mio T, Liu X, Toews ML, et al. Bradykinin augments fibroblastmediated contraction of released collagen gels. Am J Physiol Lung Cell Mol Physiol 2001; 281: L164-L171.

16 Kobayashi T, Liu X, Wen FQ, et al. Smad 3 mediates TGF- $\beta_{1}$-induced collagen gel contraction by human lung fibroblasts. Biochem Biophys Res Commun 2006; 339: 290-295.

17 Miki H, Mio T, Nagai S, et al. Glucocorticoid-induced contractility and F-actin content of human lung fibroblasts in three-dimensional culture. Am J Physiol Lung Cell Mol Physiol 2000; 278: L13-L18.

18 Boero S, Sabatini F, Silvestri M, et al. Modulation of human lung fibroblast functions by ciclesonide: evidence for its conversion into the active metabolite desisobutyryl-ciclesonide. Immunol Lett 2007; 112: 39-46.

19 Abe M, Ho $\mathrm{CH}$, Kamm KE, et al. Different molecular motors mediate platelet-derived growth factor and lysophosphatidic acidstimulated floating collagen matrix contraction. J Biol Chem 2003; 278: 47707-47712.

20 Mio T, Adachi Y, Romberger DJ, et al. Regulation of fibroblast proliferation in three-dimensional collagen gel matrix. In Vitro Cell Dev Biol Anim 1996; 32: 427-433.

21 Zocchi E, Daga A, Usai C, et al. Expression of CD38 increases intracellular calcium concentration and reduces doubling time in HeLa and 3T3 cells. J Biol Chem 1998; 273: 8017-8024.

22 Vignola AM, Mirabella F, Costanzo G, et al. Airway remodeling in asthma. Chest 2003; 123: Suppl. 3, 417S-422S.

23 Tomasek JJ, Gabbiani G, Hinz B, et al. Myofibroblasts and mechanoregulation of connective tissue remodelling. Nat Rev Mol Cell Biol 2002; 3: 349-363.

24 Montesano R, Orci L. Transforming growth factor $\beta$ stimulates collagen-matrix contraction by fibroblasts: implications for wound healing. Proc Natl Acad Sci USA 1988; 85: 4894-4897. 
25 Kamio K, Liu X, Sugiura H, et al. Prostacyclin analogs inhibit fibroblast contraction of collagen gels through the cAMP-PKA pathway. Am J Respir Cell Mol Biol 2007; 37: 113-120.

26 Ichinose $M$, Takahashi $T$, Sugiura $H$, et al. Baseline airway hyperresponsiveness and its reversible component: role of airway inflammation and airway calibre. Eur Respir J 2000; 15: 248-253.

27 Venema RC. Post-translational mechanisms of endothelial nitric oxide synthase regulation by bradykinin. Int Immunopharmacol 2002; 2: 1755-1762.

28 Lee SJ, Lee $\mathrm{WH}, \mathrm{Ki} \mathrm{SH}$, et al. $\mathrm{G} \alpha_{13}$ regulates methacholine-induced contraction of bronchial smooth muscle via phosphorylation of MLC20. Biochem Pharmacol 2009; 77: 1497-1505.

29 Emmert DA, Fee JA, Goeckeler ZM, et al. Rho-kinase-mediated $\mathrm{Ca}^{2+}$-independent contraction in rat embryo fibroblasts. Am J Physiol Cell Physiol 2004; 286: C8-C21.
30 Jeng JH, Lan WH, Wang JS, et al. Signaling mechanism of thrombin-induced gingival fibroblast-populated collagen gel contraction. Br J Pharmacol 2006; 147: 188-198.

31 Sakurada K, Seto M, Sasaki Y. Dynamics of myosin light chain phosphorylation at Ser19 and Thr18/Ser19 in smooth muscle cells in culture. Am J Physiol 1998; 274: C1563-C1572.

32 Zimmermann AG, Spychala J, Mitchell BS. Characterization of the human inosine-5'-monophosphate dehydrogenase type II gene. J Biol Chem 1995; 270: 6808-6814.

33 Wennemuth G, Blocher S, Schill WB, et al. Bradykinin increases intracellular calcium levels in rat testis peritubular cells via the B2 receptor subtype. Br J Pharmacol 2003; 138: 351-358.

34 Ricciardolo FL, Lovett M, Halliday DA, et al. Bradykinin increases intracellular calcium levels in a human bronchial epithelial cell line via the B2 receptor subtype. Inflamm Res 1998; 47: 231-235. 